\title{
Nitric oxide as a second messenger in parathyroid hormone-related protein signaling
}

\section{Kalinowski, L W Dobrucki and T Malinski}

Department of Chemistry and Biochemistry, Ohio University, Athens, Ohio, USA

(Requests for offprints should be addressed to T Malinski, Department of Chemistry and Biochemistry, Ohio University, Biochemistry Research Laboratories 136, Athens, Ohio 45701-2979, USA; Email: malinski@ohio.edu)

(L Kalinowski was on sabbatical leave from the Department of Clinical Biochemistry, Medical University of Gdansk and Laboratory of Cellular and Molecular Nephrology, Medical Research Center of the Polish Academy of Science, Poland)

\begin{abstract}
Parathyroid hormone (PTH)-related protein (PTHrP) is produced in smooth muscles and endothelial cells and is believed to participate in the local regulation of vascular tone. No direct evidence for the activation of endothelium-derived nitric oxide (NO) signaling pathway by PTHrP has been found despite attempts to identify it. Based on direct in situ measurements, it is reported here for the first time that the human $\mathrm{PTH} / \mathrm{PTHrP}$ receptor analogs, hPTH(1-34) and $\mathrm{hPTHrP}(1-34)$, stimulate NO release from a single endothelial cell. A highly sensitive porphyrinic microsensor with a response time of $0.1 \mathrm{~ms}$ and a detection limit of $1 \mathrm{nmol} / 1$ was used for the measurement of NO. Both hPTH(1-34) and hPTHrP(134) stimulated $\mathrm{NO}$ release at nanomolar concentrations. The peak concentration of $0 \cdot 1 \mu \mathrm{mol} / 1 \mathrm{hPTH}(1-34)-$ and $0 \cdot 1 \mu \mathrm{mol} / 1 \mathrm{hPTHrP}(1-34)$-stimulated $\mathrm{NO}$ release was $175 \pm 9$ and $248 \pm 13 \mathrm{nmol} / \mathrm{l}$ respectively. This represents about $30 \%-40 \%$ of maximum $\mathrm{NO}$ concentration recorded in the presence of $(0 \cdot 1 \mu \mathrm{mol} / \mathrm{l})$ calcium ionophore. Two
\end{abstract}

competitive $\mathrm{PTH} / \mathrm{PTHrP}$ receptor antagonists, $10 \mu \mathrm{mol} / 1$

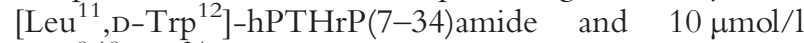
$\left[\mathrm{Nle}^{8,18}, \mathrm{Tyr}^{34}\right]-\mathrm{bPTH}(3-34)$ amide, were equipotent in antagonizing hPTH(1-34)-stimulated NO release; $\left[\mathrm{Leu}^{11}, \mathrm{D}-\mathrm{Trp}^{12}\right]-\mathrm{hPTHrP}(7-34)$ amide was more potent than $\left[\mathrm{Nle}^{8,18}, \mathrm{Tyr}^{34}\right]-\mathrm{bPTH}(3-34)$ amide in inhibiting hPTHrP(1-34)-stimulated NO release. The PKC inhibitor, H-7 $(50 \mu \mathrm{mol} / \mathrm{l})$, did not change hPTH(1-34)- and hPTHrP(1-34)-stimulated NO release, whereas the combined effect of $10 \mu \mathrm{mol} / 1$ of the cAMP antagonist, $\mathrm{Rp}$-cAMPS, and $50 \mu \mathrm{mol} / 1$ of the calmodulin inhibitor, W-7, was additive.

The present studies show that both $\mathrm{hPTH}(1-34)$ and hPTHrP(1-34) activate NO production in endothelial cells. The activation of NO release is through PTH/ PTHrP receptors and is mediated via the calcium/ calmodulin pathway.

Journal of Endocrinology (2001) 170, 433-440

\section{Introduction}

Apart from being a major physiological regulator of calcium homeostasis, parathyroid hormone $(\mathrm{PTH})$ is known to relax vascular smooth muscle and to acutely lower blood pressure in several species of vertebrates. Accordingly, PTH proved to be a potent vasodilator in dogs (Charbon 1968), rats (Pang et al. 1980a), chickens (Pang et al. 1980b), frogs (Chiu et al. 1983) and snakes (Sham et al. 1984). PTH has also been shown to lower blood pressure in hypertensive rats (Nakamura et al. 1981). Moreover, responsiveness in vivo of small arterioles to $\mathrm{PTH}$ fragment 1-34 but not fragment 3-34 indicated that N-terminally located amino acids are important for vascular dilatation (Dowe \& Joshua 1987). Despite this evidence, the relative importance of PTH as a physiological regulator of cardiovascular hemodynamics has been debated (Bukoski et al. 1995). This is, in part, due to the fact that supra- physiological concentrations of the hormone were often required to produce vasorelaxant effects.

Parathyroid hormone-related peptide (PTHrP), initially identified as a factor responsible for malignancy-associated hypercalcemia (Philbrick et al. 1996), has subsequently been demonstrated not only in tumor tissues but also in a number of normal fetal and adult tissues including vascular endothelial cells (Ishikawa et al. 1994, Rian et al. 1994, Jiang et al. 1996) and smooth muscle cells of non-vascular and vascular origin (Burton et al. 1994, Philbrick 1996). The role of PTHrP is increasingly recognized as an important autocrine/paracrine hormone in regulating physiological functions, such as local modulation of microcirculation, whereas PTH only mimics the vascular action of PTHrP. PTHrP has sequence similarity to PTH at its $\mathrm{N}$-terminus and has been shown to share its receptor with PTH in several tissues, including smooth muscle cells (Nickols et al. 1990, Urena et al. 1993) and endothelial 
cells (Amizuka et al. 1997, Jiang et al. 1998). Both PTH and PTHrP have been reported to bind to the receptor with equivalent affinity and to stimulate both adenylate cyclase and phospholipase C activities (Philbrick et al. 1996, Schluter \& Piper 1998). While the evidence linking cAMP to PTHrP-mediated vasorelaxation in different species and vascular beds is reasonably secure, the question as to whether the vasodilatory action of PTHrP involves an endothelium-derived nitric oxide (NO) signaling pathway is unresolved. It has been reported that the relaxant effect of PTH in isolated rat aorta and mesenteric vasculature did not require an intact endothelium and appeared to result from a direct effect on the vessel medial layer (Nickols et al. 1986). On the other hand, in porcine coronary arteries, removal of endothelial cells or pretreatment with $\mathrm{N}^{\mathrm{G}}$-nitro-L-arginine (L-NNA), a NO-synthase inhibitor, impaired PTH-induced relaxations (Schulze et al. 1993). In the kidney, it has been shown that the inhibition of $\mathrm{NO}$-synthase by $\mathrm{L} \mathrm{N}^{\mathrm{G}}$-nitro-L-arginine-methyl ester ( $\mathrm{L}$ NAME) markedly reduced the PTHrP-induced vasorelaxation in rabbit (Simeoni et al. 1994). However, endothelial damage in rabbit renovasculature did not alter the inhibitory action of L-NAME on PTHrP-induced vasorelaxation (Massfelder et al. 1996). On the contrary, in the more recent studies, it has been reported that PTHrPand PTH-induced aortic relaxations were largely endothelium dependent in mice (Sutliff et al. 1999). In addition, the endothelium-dependent component of PTHrP- and PTH-induced aortic relaxations was unaffected by pretreatment with L-NNA but was inhibited by pretreatment with tetrabutyl ammonium, a potassium channel blocker.

The limitation of all studies reported previously is that the release of NO was suggested based on the comparison of vascular smooth muscle relaxation and not based on direct measurement of NO. The short half-life of NO in biological systems has created several problems in its direct determination. Recently, the design and application of a porphyrinic microsensor for direct in situ electrochemical measurement of $\mathrm{NO}$ in a single cell have been published (Malinski \& Taha 1992, Hill et al. 1996). This microsensor, designed for cell culture (Hill et al. 1996), allows the direct quantification of $\mathrm{NO}$ with a high sensitivity.

The aims of the present study were to explore, by using $\mathrm{NO}$-porphyrinic microsensor, the concentration-related effect of $\mathrm{PTHrP}$ on NO release, to compare the NOstimulating potency of $\mathrm{PTHrP}$ to that of $\mathrm{PTH}$, and to evaluate signal transduction systems that are involved in PTHrP- and PTH-stimulated NO release in endothelial cells.

\section{Materials and Methods}

Cell culture

Cultured endothelial cells were derived from bovine pulmonary artery, cell line CPAE (CCL-209) from the
American Type Culture Collection (Rockville, MD, USA). Cells were grown in T-75 tissue culture flasks (Corning, Greenville, OH, USA) in minimum essential medium (MEM, Cellgro, Herndon, VA, USA) containing 10\% fetal bovine serum (FBS, Biocell Laboratories, Inc., Rancho Dominguez, CA, USA) and 0.004\% gentamycin. The culture was incubated in an atmosphere of $95 \%$ air and $5 \% \mathrm{CO}_{2}$ at $37^{\circ} \mathrm{C}$ and passaged every $3-4$ days. The cells were detached by exposure for $2-3 \mathrm{~min}$ at $24{ }^{\circ} \mathrm{C}$ to $0.05 \%$ trypsin in $0.15 \mathrm{~mol} / 1 \mathrm{NaCl}, 0.01 \mathrm{~mol} / 1$ sodium phosphate and $0.02 \%$ EDTA. Once the cells lifted off, $8 \mathrm{ml}$ of the original medium were added to the $2 \mathrm{ml}$ trypsin/cell solution (to inactivate trypsin) and centrifuged at approximately 600 r.p.m. for $10 \mathrm{~min}$. The cell pellet was resuspended in $10 \mathrm{ml}$ fresh culture medium. To maintain the culture, $4 \mathrm{ml}$ of the cell suspension were transferred to a T-75 tissue culture glass containing $11 \mathrm{ml}$ fresh growth medium. Two milliliters of the cell suspension were transferred to a $60 \times 15 \mathrm{~mm}$ tissue culture dish (Corning). The culture was then incubated $\left(37^{\circ} \mathrm{C}\right.$, in an atmosphere of $95 \%$ air and $5 \% \mathrm{CO}_{2}$ ) for 2-4 days, until the cells were confluent. Cells were rinsed twice with Hank's balanced saline solution (HBSS) containing $137 \mathrm{mmol} / 1$ $\mathrm{NaCl}, 5 \mathrm{mmol} / 1 \mathrm{KCl}, 0.8 \mathrm{mmol} / 1 \mathrm{MgSO}_{4}, 0.33 \mathrm{mmol} / \mathrm{l}$ $\mathrm{Na}_{2} \mathrm{HPO}_{4}, \quad 0.44 \mathrm{mmol} / 1 \quad \mathrm{~K}_{2} \mathrm{HPO}_{4}, 1 \mathrm{mmol} / \mathrm{l} \mathrm{MgCl}$, $1.8 \mathrm{mmol} / 1 \mathrm{CaCl}_{2}, 10 \mathrm{mmol} / 1 \mathrm{Tris}-\mathrm{HCl}$ and $1 \mathrm{mmol} / 1$ L-arginine $\left(37^{\circ} \mathrm{C}\right)$ prior to assays in order to remove growth media. All PTH and PTHrP relative peptides were dissolved in $10^{-3} \mathrm{~mol} / 1 \mathrm{HCl}$ containing $0 \cdot 1 \%$ bovine serum albumin at a final concentration of $2.5 \times 10^{-4}$ $\mathrm{mol} / \mathrm{l}$ and stored at $-70{ }^{\circ} \mathrm{C}$ in $25 \mu \mathrm{l}$ aliquots. Before use, peptides were further diluted to the desired concentration in HBSS. To study the effects of PTH and PTHrP receptor blockade, the antagonists, $\left[\mathrm{Nle}^{8,18}, \mathrm{Tyr}^{34}\right]-$ bPTH(3-34)amide and $\left[\mathrm{Leu}^{11}, \mathrm{D}-\mathrm{Trp}^{12}\right]-\mathrm{hPTHrP}$ (7-34)amide, were added to cell incubation buffer at a final concentration of $10 \mu \mathrm{mol} / 15 \mathrm{~min}$ prior to addition of the agonists, hPTH(1-34) and hPTHrP(1-34). For experiments in $\mathrm{Ca}^{2+}$-free solution, $\mathrm{Ca}^{2+}$ was omitted from HBSS solution and $2 \mathrm{mmol} / 1$ ethylene glycol-bis $(\beta-$ aminoethylether)-N,N, $\mathrm{N}^{\prime}, \mathrm{N}^{\prime}$-tetraacetic acid (EGTA) were added. In the experiments with $\mathrm{NO}$ synthase inhibitors $(200 \mu \mathrm{mol} / 1$ each), a membrane-permeable antagonist of cyclic adenosine monophosphate $(10 \mu \mathrm{mol} / \mathrm{l})$, calmodulin and protein kinase C (PKC) inhibitors $(50 \mu \mathrm{mol} / 1$ each), the cells were pretreated for $30 \mathrm{~min}$ with various blocking agents. Trifluoperazine (TFP) and n-(6aminohexyl)-5-chloro-1-naphtalene sulfonamide (W-7), calmodulin inhibitors, and forskolin, an activator of adenylate cyclase, were dissolved in dimethylsulfoxide (DMSO). Calcium ionophore (CaI) A23187 (0.1 $\mu \mathrm{mol} / \mathrm{l})$ was dissolved in absolute ethanol, acetylcholine (Ach; $0 \cdot 1 \mu \mathrm{mol} / \mathrm{l})$, 1-(5-isoquinolinylsulfonyl)-2-methyl piperazine (H-7, a PKC inhibitor), Rp-adenosine cyclic $3^{\prime}, 5^{\prime}$-phosphorothioate (Rp-cAMPS, a cAMP antagonist) and the NO synthase inhibitors, L-NAME and 
$\mathrm{N}^{\mathrm{G}}$-monomethyl-L-arginine (L-NMMA), were dissolved in HBSS. In a control experiment, an equal volume of DMSO or absolute ethanol replaced the solution of tested agents, where appropriate. The final concentrations of the vehicles in the incubation medium did not exceed $0 \cdot 1 \%$. The concentration of the endothelial NO synthase (eNOS) agonists, $\mathrm{CaI}$ and Ach used in all experiments was selected based on a dose-response curve (maximal response). NO release was measured electrochemically from a single endothelial cell. All chemicals were purchased from Sigma (St Louis, MO, USA), unless otherwise noted.

\section{Nitric oxide measurement}

Nitric oxide was prepared according to the procedures published previously (Malinski \& Taha 1992, Hill et al. 1996). The sensor operated in a three-electrode system, consisting of the sensor working electrode, a platinum wire $(0.1 \mathrm{~mm})$ counter electrode and a standard calomel reference electrode. The current proportional to NO concentration was measured by a porphyrinic sensor, which operated in amperometric mode (EG\&G PAR Model 283 Potentiostat/Galvanostat was used) at a constant potential of $0.75 \mathrm{~V}$ versus the standard calomel electrode. The response time used in these measurements was $0.1 \mathrm{~ms}$ and the detection limit was $10^{-9} \mathrm{~mol} / \mathrm{l}$. The $\mathrm{NO}$ concentration was determined from the measured current by means of a calibration curve (nitric oxide standard saturated aqueous solution with an $\mathrm{NO}$ concentration of $1.76 \mathrm{mmol} / \mathrm{l})$. The working electrode (NO sensor) was placed close to the surface $(20 \pm 5 \mu \mathrm{m})$ of the cell membrane with the help of a computer-controlled micromanipulator. NO was measured as an increase of the current from its background.

\section{Statistical analysis}

Statistical evaluation was carried out using ANOVA followed by Student-Newman-Keul's test. Values are expressed as means \pm s.E.M., with $P<0.05$ considered statistically significant. In each set of experiments, $n$ is the number of culture dishes studied.

\section{Results}

A typical high-resolution amperometric curve (concentration of $\mathrm{NO}$ recorded versus time) obtained during $\mathrm{CaI}$ A23187-stimulated NO release from a single bovine endothelial cell is depicted in Fig. 1. Immediately after addition of $\mathrm{CaI}(0 \cdot 1 \mu \mathrm{mol} / \mathrm{l})$, NO was released resulting in a sharp peak of $583 \pm 30 \mathrm{nmol} / 1(n=5)$ about $1 \mathrm{~s}$ after stimulation. The rate of concentration increase was $305 \mathrm{nmol} / \mathrm{l} / \mathrm{s}$. The peak concentration stimulated by a receptor-independent eNOS agonist represents the maximum NO concentration that can be released by a

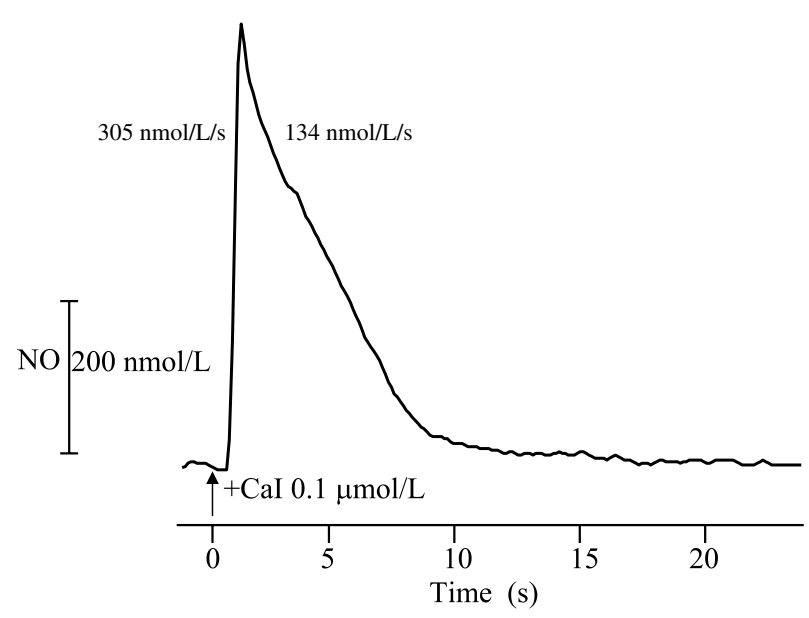

Figure 1 Change in $\mathrm{NO}$ concentration with time on the surface of a single endothelial cell (pulmonary artery) after stimulation with $0 \cdot 1 \mu \mathrm{mol} / \mathrm{l} \mathrm{Cal} \mathrm{A} 23187$.

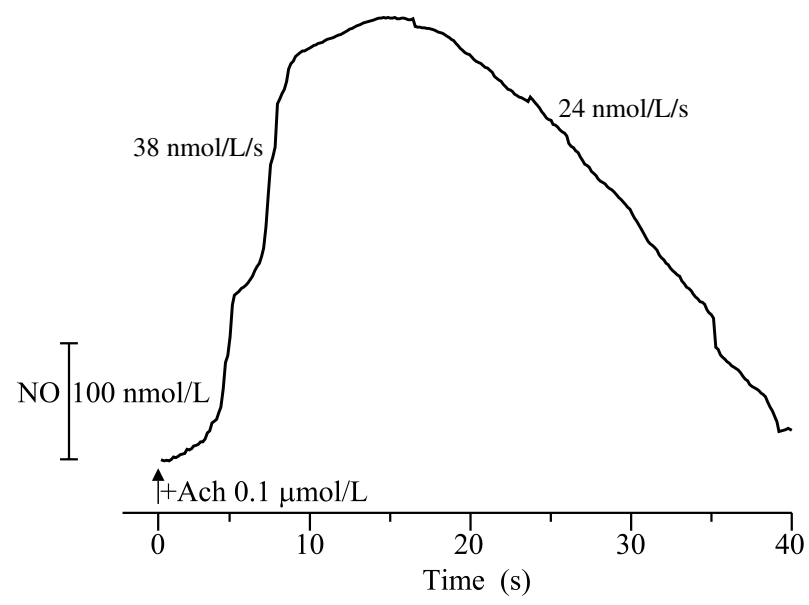

Figure 2 Change in NO concentration with time on the surface of a single endothelial cell (pulmonary artery) after stimulation with $0 \cdot 1 \mu \mathrm{mol} / \mathrm{l}$ Ach.

particular endothelial cell. After reaching the sharp peak of $\mathrm{NO}$ concentration, a rapid decrease of NO concentration with a rate of $134 \mathrm{nmol} / \mathrm{l} / \mathrm{s}$ was observed.

A different pattern of $\mathrm{NO}$ release was observed after stimulation with $0 \cdot 1 \mu \mathrm{mol} / 1 \mathrm{Ach}$, a receptor-dependent eNOS agonist (Fig. 2). The peak NO concentration was $388 \pm 20 \mathrm{nmol} / \mathrm{l}(n=5)$, which represented about $65 \%$ of the maximum concentration achieved in the presence of CaI. Also, the kinetics of Ach-stimulated NO release was slower than those of CaI-stimulated release. An increase in $\mathrm{NO}$ concentration was recorded $4 \mathrm{~s}$ after the addition of Ach. The rate of NO release amounted to $38 \mathrm{nmol} / \mathrm{l} / \mathrm{s}$, which was almost 10 times slower than the rate of CaI-stimulated NO release. A semi-plateau was reached after $8 \mathrm{~s}$ and after about $24 \mathrm{~s}$ a slow decrease of NO concentration with a rate of $24 \mathrm{nmol} / \mathrm{l} / \mathrm{s}$ was recorded. 


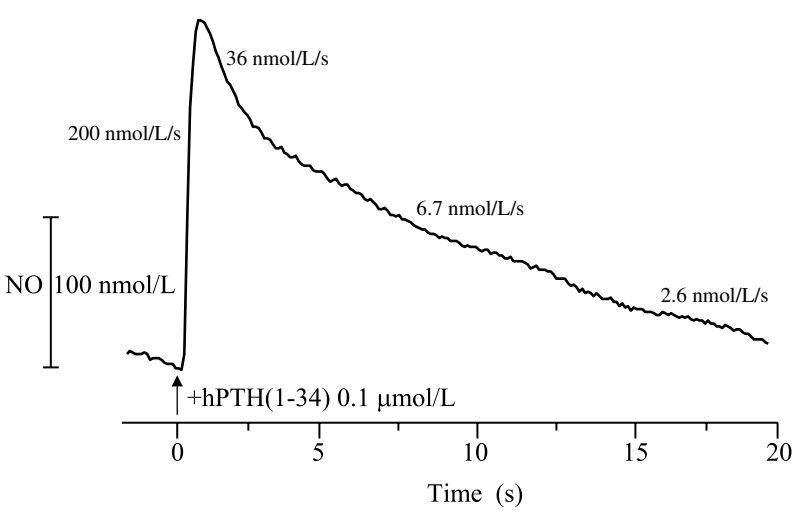

Figure 3 Change in NO concentration with time on the surface of a single endothelial cell (pulmonary artery) after stimulation with $0 \cdot 1 \mu \mathrm{mol} / \mathrm{l} \mathrm{hPTH}(1-34)$.

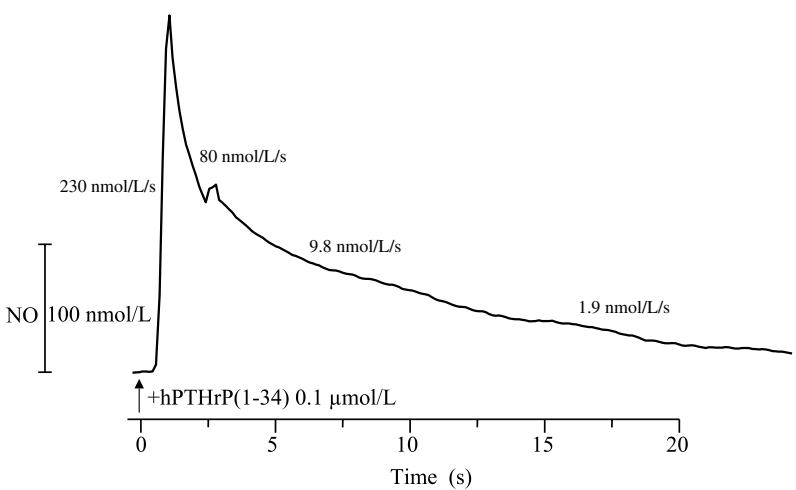

Figure 4 Change in NO concentration with time on the surface of a single endothelial cell (pulmonary artery) after stimulation with $0 \cdot 1 \mu \mathrm{mol} / \mathrm{l} \mathrm{hPTHrP}(1-34)$.

Figures 3 and 4 show representative amperometric curves for $\mathrm{NO}$ release from bovine endothelial cells measured after addition of $0 \cdot 1 \mu \mathrm{mol} / 1 \mathrm{hPTH}(1-34)$ and $0 \cdot 1 \mu \mathrm{mol} / 1 \mathrm{hPTHrP}(1-34)$ respectively. The kinetics of $\mathrm{NO}$ release after stimulation with $\mathrm{hPTH}(1-34)$ and hPTHrP(1-34) were very similar. Moreover, the patterns of NO release stimulated by both agents represented mixed features of the patterns of $\mathrm{NO}$ release recorded for $\mathrm{CaI}$ and Ach. While increases in NO concentration were recorded after the addition of either $\mathrm{hPTH}(1-34)$ or $\mathrm{hPTHrP}(1-34)$, the patterns resembled the kinetics of $\mathrm{NO}$ release after stimulation with $\mathrm{CaI}$. The rate of $\mathrm{NO}$ release was $200 \mathrm{nmol} / \mathrm{l} / \mathrm{s}$ for $\mathrm{hPTH}(1-34)$ and $230 \mathrm{nmol} / \mathrm{l} / \mathrm{s}$ for hPTHrP(1-34). NO concentration peaked at $175 \pm 9 \mathrm{nmol} / \mathrm{l}$ after stimulation with $\mathrm{hPTH}(1-34)$ and at $248 \pm 13 \mathrm{nmol} / 1$ after stimulation with $\mathrm{hPTHrP}(1-34)$ ( $n=6$ each). The maximal concentration of $\mathrm{NO}$ was significantly smaller after stimulation with $0 \cdot 1 \mu \mathrm{mol} / 1$ hPTH(1-34) than with $0 \cdot 1 \mu \mathrm{mol} / 1 \mathrm{hPTHrP}(1-34)$. It represented about $30 \%$ and $40 \%$ of the maximum concentration achieved in the presence of $\mathrm{CaI}$, for $\mathrm{hPTH}(1-34)$

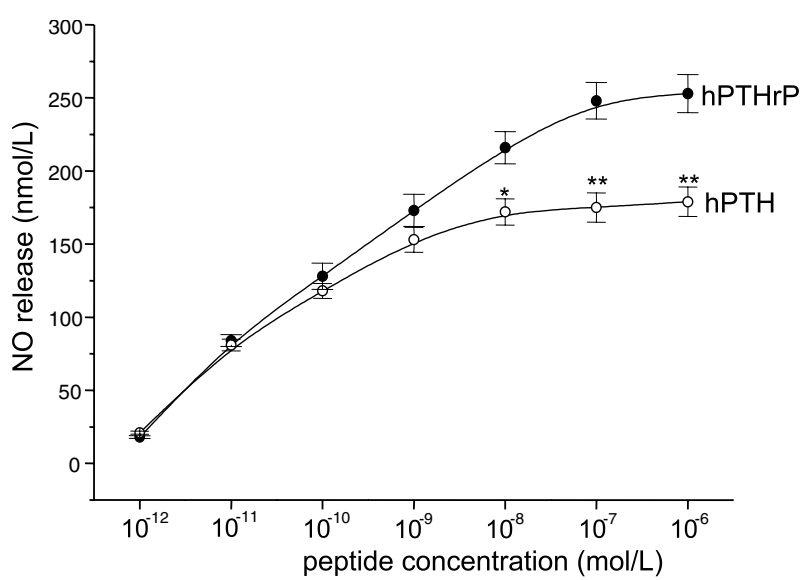

Figure 5 Dose-response curve for the peak NO release from an endothelial cell (pulmonary artery) after stimulation with $\mathrm{hPTH}(1-34)$ (open circles) and hPTHrP(1-34) (solid circles). ${ }^{*} P<0 \cdot 05,{ }^{*} P<0 \cdot 01$ vs hPTHrP.

and hPTHrP(1-34) respectively. After reaching the sharp peak of NO concentration after addition of both analogs, decreases in NO concentrations were more similar to the pattern of NO decay observed for Ach than for CaI. The initial rate of the decrease of $\mathrm{NO}$ concentration was slower for hPTH(1-34) than for hPTHrP(1-34) $(36 \mathrm{nmol} / \mathrm{l} / \mathrm{s}$ vs $80 \mathrm{nmol} / \mathrm{l} / \mathrm{s}$ respectively). However, the rate of $\mathrm{NO}$ decay for both peptides was significantly faster (1.5-3 times) after stimulation with Ach. After $2.5 \mathrm{~s}$, a further decrease in the rate of $\mathrm{NO}$ decay was observed: $6.7 \mathrm{nmol} / \mathrm{l} / \mathrm{s}$ for $\mathrm{hPTH}(1-34)$ and $9 \cdot 8 \mathrm{nmol} / \mathrm{l} / \mathrm{s}$ for $\mathrm{hPTHrP}(1-34)$. After $13 \mathrm{~s}$, a further decrease in NO concentration with a rate of $2.6 \mathrm{nmol} / \mathrm{l} / \mathrm{s}$ for $\mathrm{hPTH}(1-34)$ and $1.9 \mathrm{nmol} / \mathrm{l} / \mathrm{s}$ for hPTHrP(1-34) was observed. After about $20 \mathrm{~s}$, both hPTH(1-34)- and hPTHrP(1-34)-stimulated NO release decreased almost to zero level. It should be noted that the amperograms for NO release depicted in Figs 1-4 were highly reproducible for each of the test substances. Also, the traces of $\mathrm{NO}$ production were consistent in relation to maximum concentration as well as to the change in NO concentration with time in all preparations of endothelial cells.

Concentration-response curves of the peak NO release for hPTH(1-34) and hPTHrP(1-34) are shown in Fig. 5 $(n=6$ each point). There is a linear response for both analogs in the range of concentrations between $10^{-12}$ $\mathrm{mol} / \mathrm{l}$ and $10^{-9} \mathrm{~mol} / \mathrm{l}$. At concentrations of $\mathrm{hPTH}(1-34)$ or $\mathrm{hPTHrP}(1-34)$ higher than $10^{-9} \mathrm{~mol} / \mathrm{l}$, a significant deviation from the linear relationship was observed. A semi-plateau was reached at concentrations of both $\mathrm{hPTH}(1-34)$ and hPTHrP(1-34) higher than $0 \cdot 1 \mu \mathrm{mol} / 1$. hPTHrP(1-34) showed a higher NO release than $\mathrm{hPTH}(1-34)$ at concentrations above $10^{-9} \mathrm{~mol} / \mathrm{l}$ $(P<0 \cdot 05)$.

As expected, both $0 \cdot 1 \mu \mathrm{mol} / 1 \mathrm{CaI}-$ and $0 \cdot 1 \mu \mathrm{mol} / 1$ Ach-stimulated NO release was inhibited by $100 \mu \mathrm{mol} / 1$ 

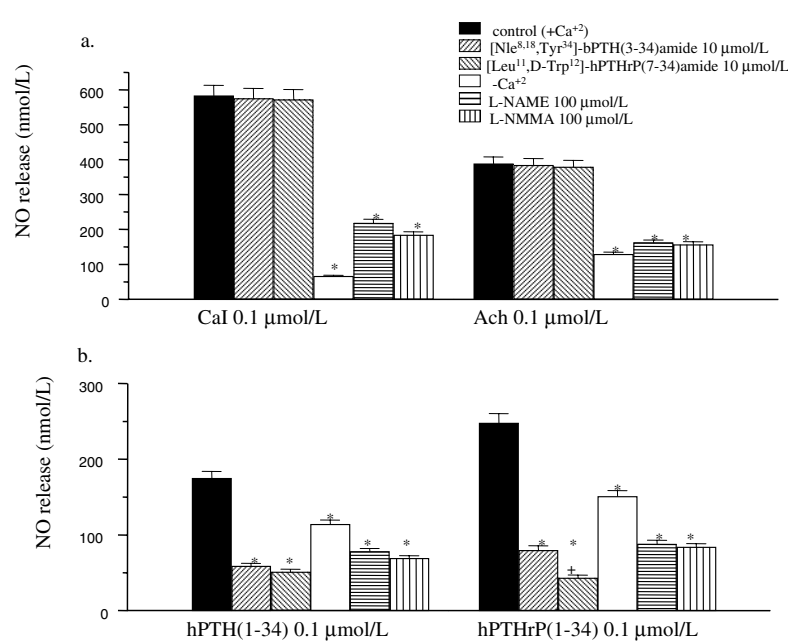

Figure $6 \mathrm{NO}$ release stimulated by $0 \cdot 1 \mu \mathrm{mol} / \mathrm{l}$ Cal A 23187 and $0 \cdot 1 \mu \mathrm{mol} / \mathrm{l}$ Ach (Fig. 6a), and $0.1 \mu \mathrm{mol} / \mathrm{l} \mathrm{hPTH}(1-34)$ and $0.1 \mu \mathrm{mol} / \mathrm{l} \mathrm{hPTHrP}(1-34)$ (Fig. 6b) in the presence and absence of extracellular $\mathrm{Ca}^{2+}$, in the presence of $100 \mu \mathrm{mol} / \mathrm{l}$ L-arginine analogues: L-NAME or L-NMMA and in the presence of $10 \mu \mathrm{mol} / \mathrm{l}$ competitive PTH/PTHrP receptor antagonists: $\left[\mathrm{Nle}^{8,18}, \mathrm{Tyr}^{34}\right]$-bPTH(3-34)amide and [ $\left[\right.$ Leu $\left.^{11}, \mathrm{D}-\mathrm{Trp}^{12}\right]$-hPTHrP (7-34)amide. ${ }^{*} P<0 \cdot 01$ vs control $\left(+\mathrm{Ca}^{2+}\right) ;{ }^{+} P<0 \cdot 01$ vs $\left[\mathrm{Nle}^{8,18}, \mathrm{Tyr}^{34}\right]-\mathrm{bPTH}(3-34)$ amide.

L-NAME and $100 \mu \mathrm{mol} / 1 \mathrm{~L}-\mathrm{NMMA}$ (Fig. $6 ; n=6$ each bar). The average inhibition was about $60 \%$ for both NOS agonists. Similarly, both $0 \cdot 1 \mu \mathrm{mol} / 1 \mathrm{hPTH}(1-34)-$ and $0 \cdot 1 \mu \mathrm{mol} / 1 \mathrm{hPTHrP}(1-34)$-stimulated $\mathrm{NO}$ production was inhibited: by $55 \pm 3 \%$ and $63 \pm 4 \%$ respectively in the presence of L-NAME and by $60 \pm 4 \%$ and $65 \pm 4 \%$ respectively in the presence of L-NMMA $(P<0 \cdot 01)$. In the $\mathrm{Ca}^{2+}$-free buffer $(2 \mathrm{mmol} / 1$ EGTA was also added to chelate residual $\mathrm{Ca}^{2+}$ ) the peak concentration of $\mathrm{NO}$ stimulated by all tested agents was significantly diminished by $88 \% \pm 5$ (CaI), $67 \% \pm 5$ (Ach), $35 \% \pm 2(\mathrm{hPTH}(1-$ $34))$ and $39 \% \pm 2(\mathrm{hPTHrP}(1-34))$. Two competitive $\mathrm{PTH} / \mathrm{PTHrP}$ receptor antagonists at concentrations of $10 \mu \mathrm{mol} / 1, \quad\left[\mathrm{Nle}^{8,18}, \mathrm{Tyr}^{34}\right]-\mathrm{bPTH}(3-34)$ amide and $\left[\mathrm{Leu}^{11}, \mathrm{D}-\mathrm{Trp}^{12}\right]-\mathrm{hPTHrP}(7-34)$ amide were devoid of agonist activity, but markedly inhibited the $\mathrm{NO}$ increase elicited by both hPTH(1-34) and $\mathrm{hPTHrP}(1-34)$. The inhibition of NO release was $67 \% \pm 3$ and $69 \% \pm 3$ in the presence of $\left[\mathrm{Nle}^{8,18}, \mathrm{Tyr}^{34}\right]-\mathrm{bPTH}(3-34)$ amide and $70 \% \pm 4$ and $82 \% \pm 4$ in the presence of $\left[\mathrm{Leu}^{11}, \mathrm{D}-\mathrm{Trp}^{12}\right]-$ hPTHrP(7-34)amide after stimulation with hPTH(1-34) and hPTHrP(1-34) respectively $(P<0 \cdot 01)$. The PTH/ $\mathrm{PTHrP}$ receptor antagonists were equipotent in antagonizing hPTH(1-34)-stimulated NO release, whereas the inhibitory effect of $\left[\mathrm{Leu}^{11}, \mathrm{D}-\mathrm{Trp}^{12}\right]-\mathrm{hPTHrP}(7-34)$ amide on hPTHrP(1-34)-stimulated NO release was significantly higher compared with that of the same dose of $\left[\mathrm{Nle}^{8,18}, \mathrm{Tyr}^{34}\right]-\mathrm{bPTH}(3-34)$ amide $(P<0 \cdot 05)$. The antagonists had no measurable effect on NO response after addition of either CaI or Ach.

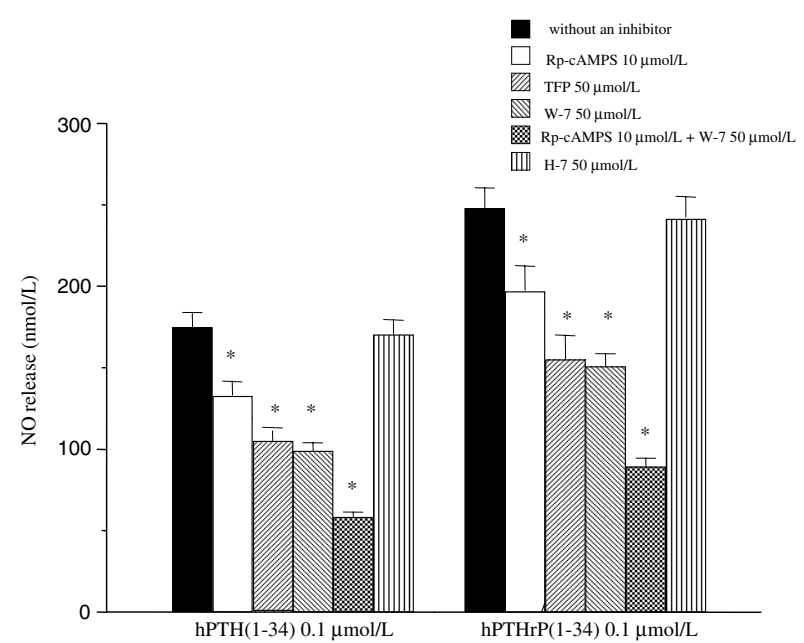

Figure $7 \mathrm{NO}$ release stimulated by $0 \cdot 1 \mu \mathrm{mol} / \mathrm{l} \mathrm{hPTH}(1-34)$ and $0 \cdot 1 \mu \mathrm{mol} / \mathrm{l} \mathrm{hPTHrP}(1-34)$ in the presence of $10 \mu \mathrm{mol} / \mathrm{I} \mathrm{Rp}$-cAMPS (a cAMP antagonist), $50 \mu \mathrm{mol} / \mathrm{I}$ TFP or W-7 (calmodulin inhibitors), $10 \mu \mathrm{mol} / \mathrm{l} \mathrm{Rp-CAMPS}+50 \mu \mathrm{mol} / \mathrm{l} \mathrm{W}-7$, or $50 \mu \mathrm{mol} / \mathrm{l} \mathrm{H}-7$ (a PKC inhibitor). ${ }^{*} P<0 \cdot 01$ vs without an inhibitor (solid bars) $(0.1 \mu \mathrm{mol} / \mathrm{l}$ $\mathrm{hPTH}(1-34)$ or $0 \cdot 1 \mu \mathrm{mol} / \mathrm{l} \mathrm{hPTHrP}(1-34)$ alone).

The addition of $10 \mu \mathrm{mol} / 1 \mathrm{Rp}$-cAMPS (a cAMP antagonist) significantly reduced, but did not completely prevent, the hPTH(1-34)- and hPTHrP(1-34)-stimulated NO release, by $22 \pm 4 \%$ and $25 \pm 3 \%$ respectively $(P<0 \cdot 01)$ (Fig. 7; $n=6$ each bar). As expected, $0 \cdot 1 \mu \mathrm{mol} / 1$ Ach (cAMP independent NO agonist)-stimulated NO release was not significantly affected by Rp-cAMPS (data not shown). The addition of $50 \mu \mathrm{mol} / 1$ of the calmodulin inhibitors, TFP or W-7, reduced but did not completely prevent either hPTH(1-34)- and hPTHrP(1-34)stimulated NO release. Both hPTH(1-34)- and hPTHrP(1-34)-stimulated NO release was inhibited by $37 \pm 2 \%$ and $38 \pm 3 \%$ respectively in the presence of TFP and by $43 \pm 3 \%$ and $41 \pm 4 \%$ respectively in the presence of W-7 $(P<0 \cdot 01)$. By contrast, in the presence of $50 \mu \mathrm{mol} / 1 \mathrm{H}-7$ (a PKC inhibitor), both hPTH(1-34)- and hPTHrP(1-34)-stimulated NO release was unaltered. The combined effect of Rp-cAMPS and $\mathrm{W}-7$ on either hPTH(1-34)- or hPTHrP(1-34)-stimulated NO release was additive.

With a view to confirming the involvement of adenylate cyclase activation in the peptide-mediated NO production, the effect of different concentrations of forskolin on NO release in endothelial cells was also studied. Forskolin produced a concentration-dependent linear increase of the peak NO release with $1 \mu \mathrm{mol} / 1$ being the threshold concentration of the compound. Rp-cAMPS $(10 \mu \mathrm{mol} / \mathrm{l})$ significantly inhibited the NO release induced by forskolin (Fig. $8 ; n=6$ each point).

\section{Discussion}

While the evidence linking the adenylyl cyclase transduction pathway to PTHrP-mediated vasorelaxation is well 


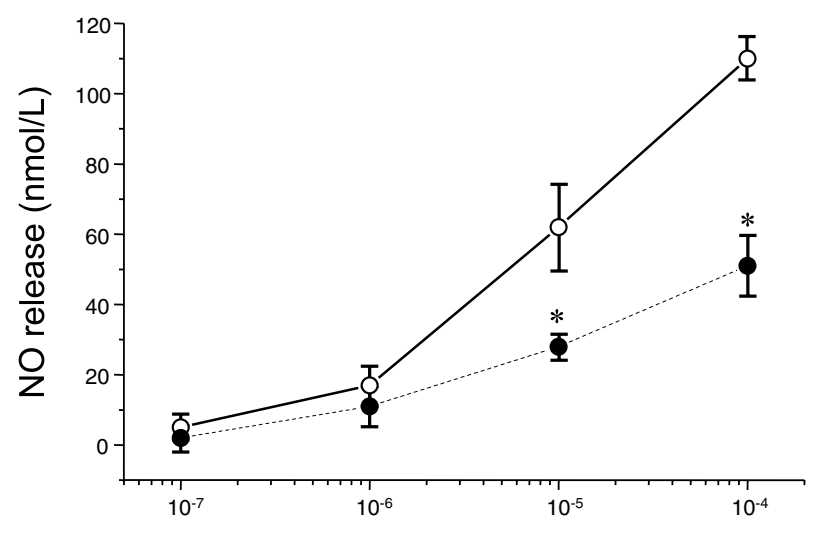

Forskolin concentration (mol/L)

Figure 8 The peak concentration of $\mathrm{NO}$ released from an endothelial cell (pulmonary artery) after stimulation with different concentrations of forskolin in the presence (solid circles) or absence (open circles) of $10 \mu \mathrm{mol} / \mathrm{l}$ Rp-cAMPS. ${ }^{*} P<0 \cdot 01$ vs without Rp-cAMPS.

proven (Schluter \& Piper 1998), the involvement of an endothelium-derived NO signaling pathway has not been indicated despite attempts to identify it. These studies provide, for the first time, direct in situ measurements of NO after stimulation by PTH (hPTH(1-34)) and PTHrP (hPTHrP(1-34)) close to the membrane of endothelial cells. The cell membrane does not present a barrier to the diffusion of $\mathrm{NO}$ and is not a rate-determining factor in its propagation between cells. On the membrane of endothelial cells, the concentration of $\mathrm{NO}$ is three to four times higher than that in the cytoplasm (Kiechle \& Malinski 1993). From an analytical point of view, the detection of $\mathrm{NO}$ in the location with the highest concentration, the surface of the cell membrane, is the most efficient and accurate method of measuring endogenous NO levels. The short half-life of $\mathrm{NO}$ and its loss due to reaction with transition metals or free radicals make accurate quantitative measurements of NO difficult. Most current methods for $\mathrm{NO}$ detection are indirect, relying on measurements of secondary species such as nitrite removed from biological systems, or on bioassays that rely on secondary effects. The hPTHrP(1-34) concentrations that stimulate NO release in endothelium may be considered physiologically relevant, as PTHrP has a potent vasorelaxant activity with $\mathrm{EC}_{50}$ values in the nanomolar range. $\mathrm{hPTHrP}(1-34)$ at concentrations higher than $100 \mathrm{nM}$ produced a greater increase in $\mathrm{NO}$ concentrations as compared with the same dose of hPTH(1-34). It has previously been found independently of the experimental model used (Schluter \& Piper 1998), that $\mathrm{PTHrP}(1-34)$ is more potent than $\mathrm{PTH}(1-34)$ in vasodilation. It can be assumed that the discrepancy of both peptides in vasorelaxant potency is due, in part, to the different ability for stimulation of $\mathrm{NO}$ in endothelial cells.
Amino terminally truncated PTH and PTHrP peptides are potent $\mathrm{PTH} / \mathrm{PTHrP}$ receptor antagonists. In the present study, two competitive $\mathrm{PTH} / \mathrm{PTHrP}$ receptor antagonists, $\quad\left[\mathrm{Leu}^{11}, \mathrm{D}-\mathrm{Trp}^{12}\right]-\mathrm{hPTHrP}(7-34)$ amide and $\left[\mathrm{Nle}^{8,18}, \mathrm{Tyr}^{34}\right]-\mathrm{bPTH}(3-34)$ amide, markedly antagonized both hPTH(1-34)- and hPTHrP(1-34)-stimulated NO release in endothelial cells. This clearly suggests that stimulation of NO release occurred via the PTH/PTHrP receptor mechanism. On the other hand, the analogs were equipotent in antagonizing hPTH(1-34)-stimulated $\mathrm{NO}$ release, whereas $\left[\mathrm{Leu}^{11}{ }^{1}, \mathrm{D}-\operatorname{Trp}^{12}\right]-\mathrm{hPTHrP}(7-34)$ amide was more potent than $\left[\mathrm{Nle}^{8,18}, \mathrm{Tyr}^{34}\right]$-bPTH(3-34)amide in inhibiting $\mathrm{hPTHrP}(1-34)$-stimulated $\mathrm{NO}$ release. These findings indicate that part of hPTHrP(1-34) other than the first two amino acids contribute to its activation of $\mathrm{NO}$ production. hPTHrP(1-34) was more potent than $\mathrm{hPTH}(1-34)$ in the stimulation of NO production, a fact which may be of importance in the speculation on the possible physiological functions of PTH and PTHrP. In contrast to PTHrP, PTH has so far been localized only in the parathyroid glands, hypothalamus and pituitary in all vertebrates (Pang et al. 1988, Philbrick et al. 1996). The amount of PTH required to produce a vasorelaxant effect is still much higher than is found in the circulation; the circulating levels of PTH in humans and animals are in the order of 0.025 nM (Bukoski et al. 1995). Thus it seems that under normal physiological conditions PTHrP is the endogenous ligand and PTH mimics the vascular action of PTHrP pharmacologically.

NO produced by vascular endothelial cells is synthesized by $\mathrm{Ca}^{2+}$-dependent constitutive $\mathrm{NO}$ synthase (eNOS) (Bredt \& Snyder 1990). Both hPTH(1-34) and hPTHrP(1-34) activated eNOS to release NO. The release of $\mathrm{NO}$ was inhibited by the analogs of $\mathrm{L}$-arginine, L-NAME and L-NMMA. The $\mathrm{Ca}^{2+}$ that activates the eNOS may originate from intracellular stores or from the extracellular space. It has been demonstrated that the release of NO strongly depends on the entry of extracellular $\mathrm{Ca}^{2+}$ (Bredt \& Snyder 1990). Data presented here indicate that the removal of extracellular $\mathrm{Ca}^{2+}$ significantly affected, to an equal extent, the release of $\mathrm{NO}$ stimulated by both $\mathrm{hPTH}(1-34)$ and $\mathrm{hPTHrP}(1-34)$. Numerous experimental data suggest that either $\mathrm{PTH}$ or $\mathrm{PTHrP}$ exert their vasorelaxant action via cAMP-dependent inhibition of L-type $\mathrm{Ca}^{2+}$ channel currents in vascular smooth muscle cells (Philbrick et al. 1996, Schluter \& Piper 1998). Little data exist with regard to the effect of the peptides on endothelial $\mathrm{Ca}^{2+}$ content. It has been reported that intracellular $\mathrm{Ca}^{2+}$ of human vascular endothelial cells was raised by intact $\mathrm{PTH}(1-84)$, but fragment $1-34$ had no effect in human vascular and bovine bone-derived endothelial cells (Fujita et al. 1992, Ida et al. 1994). The present study revealed that pharmacological blockage of the cAMP/ protein kinase A-dependent process partially reduced both hPTH(1-34)- and hPTHrP(1-34)-stimulated NO release. However, additional second messenger pathways must be 
involved in $\mathrm{hPTH}(1-34) / \mathrm{hPTHrP}(1-34)$ formation since the combined effect of both Rp-cAMPS and W-7 inhibitors was additive. It suggested that the phospholipase C/phosphatidylinositol 4,5-biphosphate $\left(\mathrm{PIP}_{2}\right)$ turnover pathway is involved in mediating this effect. On the other hand, the PKC inhibitor, $\mathrm{H}-7$, was unable to inhibit $\mathrm{NO}$ formation response to $\mathrm{hPTH}(1-34)$ or $\mathrm{hPTHrP}(1-34)$. Moreover, the combined effect of the inhibitors on hPTH(1-34)- and hPTHrP(1-34)-stimulated NO release was higher than the effect after the removal of extracellular $\mathrm{Ca}^{2+}$ and was comparable with the effect of L-NAME or L-NMMA. It suggests also a possible role for the release of $\mathrm{Ca}^{2+}$ from intracellular stores after stimulation of NO formation with $\mathrm{hPTH}(1-34)$ or $\mathrm{hPTHrP}(1-34)$. It is known that hydrolysis of $\mathrm{PIP}_{2}$ by phospholipase $\mathrm{C}$ yields the other inositol 1,4,5-triphosphate $\left(\mathrm{IP}_{3}\right)$ and subsequently may result in the influx of extracellular $\mathrm{Ca}^{2+}$ and $\mathrm{Ca}^{2+}$ release from the intracellular stores in endothelial cells (Busse et al. 1994). Since H-7 had no effect on the peptides-stimulated NO production, it does not follow that $\mathrm{PKC}$ via the $\mathrm{PIP}_{2} /$ diacylglycerol transduction pathway is involved in mediating this effect. In turn, the experiments with forskolin, which does not provoke phospathidylinositol 4,5-biphosphate breakdown, additionally confirm that activation of adenylate cyclase is associated with $\mathrm{NO}$ production in endothelial cells. The exact cAMP/protein kinase A-dependent mechanism which leads to stimulation of NO release with hPTH(134) or hPTHrP(1-34) in endothelial cells will need further investigation. At present, it is possible to speculate that, as in smooth muscle cells (Wang et al. 1991), the effect of PTH(1-34) or PTHrP(1-34) on L-type $\mathrm{Ca}^{2+}$ channel currents may be mediated by cAMP.

It can be considered that PTHrP (or PTH) induces relaxation by stimulation (or inhibition) of signaling pathways that differ among different vascular beds and possibly also between different species. For instance, in experiments with mice, PTHrP- and PTH-induced aortic relaxations were largely endothelium dependent, whereas an intact endothelium was not necessary for maximal portal vein relaxation (Sutliff et al. 1999). In the same studies, the endothelium-dependent component of PTHrP- and PTH-induced aortic relaxation was prevented by pretreatment with tetrabutyl ammonium (TBA), a potassium channel blocker. In this regard, it has been suggested that incomplete inhibition of NO production may enable low levels of $\mathrm{NO}$ that can activate the TBA-sensitive potassium channel (Cohen et al. 1997). On the other hand, in vessels of rabbit kidney, activation of both adenylyl cyclase/protein kinase A and NO-synthase/ guanylyl cyclase pathways are directly linked to the renodilatory action of PTHrP (Massfelder et al. 1996). Along with this assumption, both a marked increase in cAMP and a small increase in cGMP were seen in rabbit aortic strips during PTH-induced relaxation (Nickols \& Cline 1987). Moreover, the vasodilating property which
hPTHrP(1-34) has shown may be mediated, in part, through its inhibitory effect on endothelin-1 production, which is probably mediated through $\mathrm{NO}$ and cGMP in pulmonary arterial endothelial cells (Jiang et al. 1996).

Apart from being a crucial vasorelaxant agent, NO given locally exerts potent antiatherosclerotic effects, such as inhibition of smooth muscle proliferation, inhibition of platelet aggregation, inhibition of adhesion leukocytes and the expression of leukocyte adhesion molecules (Munzel et al. 1997). It has recently been reported that both hPTHrP(1-34) and hPTH(1-34) inhibit the migration and proliferation of cultured vascular smooth muscle cells through PTH/PTHrP receptors (Ishikawa et al. 1998). It prompts the suggestion that the antiatherosclerotic effect of PTHrP could be, at least partially, influenced by a release of $\mathrm{NO}$ from the endothelium.

In conclusion, the present studies clearly indicate that the N-terminal fragments of PTHrP and PTH, as well as exhibiting the well known vasorelaxing action via cAMPdependent inhibition of L-type $\mathrm{Ca}^{2+}$ channel currents in smooth muscle cells, are also potent activators of endothelium-derived NO production. The NO release is presumably mediated through $\mathrm{PTH} / \mathrm{PTHrP}$ receptors and dependent on a combination of pathways (cAMP, PIP 2 ) converged on $\mathrm{Ca}^{2+} /$ calmodulin effector.

\section{Acknowledgements}

This work was supported in part by grants from the United States Public Health Service (HL-60900).

\section{References}

Amizuka N, Lee HS, Kwan MY, Arazani A, Warshawsky H, Hendy GN, Ozawa H, White JH \& Goltzman D 1997 Cell-specific expression of the parathyroid hormone (PTH)/PTH-related peptide receptor gene in kidney from kidney-specific and ubiquitous promoters. Endocrinology 138 469-481.

Bredt DS \& Snyder SH 1990 Isolation of nitric oxide synthetase, a calmodulin-requiring enzyme. PNAS 87 682-685.

Bukoski RD, Ishibashi K \& Bian K 1995 Vascular actions of the calcium-regulating hormones. Seminars in Nephrology 15 536-549.

Burton DW, Brandt DW \& Deftos LJ 1994 Parathyroid hormonerelated protein in the cardiovascular system. Endocrinology 135 253-261.

Busse R, Hecker M \& Fleming I 1994 Control of nitric oxide and prostacyclin synthesis in endothelial cells. Arzneimittelforschung 44 392-396.

Charbon GA 1968 A rapid and selective vasodilator effect of parathyroid hormone. European Journal of Pharmacology 3 275-278.

Chiu KW, Uchiyama M \& Pang PK 1983 Cardiovascular effects of bPTH-(1-34) in the frog, Rana sp. Comparative Biochemistry and Physiology C 74 99-101.

Cohen RA, Plane F, Najibi S, Huk I, Malinski T \& Garland CJ 1997 Nitric oxide is the mediator of both endothelium-dependent relaxation and hyperpolarization of the rabbit carotid artery. PNAS 94 4193-4198.

Dowe JP \& Joshua IG 1987 In vivo arteriolar dilation in response to parathyroid hormone fragments. Peptides 8 443-448. 
Fujita T, Fukase M, Baba H, Yamaguchi T, Takata S, Fujimi T, Nishikawa M \& Nakamoto C 1992 New actions of parathyroid hormone through its degradation. Journal of Endocrinological Investigation 15 121-127.

Hill N, Pierchala B, Johns A, Kiechle FL, Rubanyi GM \& Malinski T 1996 In situ measurements of nitric oxide release from endothelial cells grown directly on a porphyrinic sensor. Endothelium $\mathbf{4}$ 63-69.

Ida R, Lee A, Huang J, Brandi ML \& Yamaguchi DT 1994 Prostaglandin-stimulated second messenger signaling in bonederived endothelial cells is dependent on confluency in culture. Journal of Cellular Physiology 160 585-595.

Ishikawa M, Ouchi Y, Akishita M, Kozaki K, Toba K, Namiki A, Yamaguchi T \& Orimo H 1994 Immunocytochemical detection of parathyroid hormone-related protein in vascular endothelial cells. Biochemical and Biophysical Research Communications 199 547-551.

Ishikawa M, Akishita M, Kozaki K, Toba K, Namiki A, Yamaguchi T, Orimo H \& Ouchi Y 1998 Amino-terminal fragment (1-34) of parathyroid hormone-related protein inhibits migration and proliferation of cultured vascular smooth muscle cells. Atherosclerosis 136 59-66.

Jiang B, Morimoto S, Fukuo K, Hirotani A, Tamatani M, Nakahashi T, Nishibe A, Niinobu T, Hata S, Chen S \& Ogihara T 1996 Parathyroid hormone-related protein inhibits endothelin-1 production. Hypertension 27 360-363.

Jiang B, Morimoto S, Yang J, Niinoabu T, Fukuo K \& Ogihara T 1998 Expression of parathyroid hormone/parathyroid hormonerelated protein receptor in vascular endothelial cells. Journal of Cardiovascular Pharmacology 31 (Suppl 1) S142-S144.

Kiechle FL \& Malinski T 1993 Nitric oxide. Biochemistry, pathophysiology, and detection. American Journal of Clinical Pathology 100 567-575.

Malinski T \& Taha Z 1992 Nitric oxide release from a single cell measured in situ by a porphyrinic-based microsensor [see comments]. Nature 358 676-678.

Massfelder T, Stewart AF, Endlich K, Soifer N, Judes C \& Helwig JJ 1996 Parathyroid hormone-related protein detection and interaction with $\mathrm{NO}$ and cyclic AMP in the renovascular system. Kidney International 50 1591-1603.

Munzel T, Heitzer T \& Harrison DG 1997 The physiology and pathophysiology of the nitric oxide/superoxide system. Herz 22 158-172.

Nakamura R, Watanabe TX \& Sokabe H 1981 Acute hypotensive action of parathyroid hormone-(1-34) fragments in hypertensive rats. Proceedings of the Society for Experimental Biology and Medicine 168 168-171.

Nickols GA \& Cline WH Jr 1987 Parathyroid hormone-induced changes in cyclic nucleotide levels during relaxation of the rabbit [correction of rat] aorta. Life Sciences 40 2351-2359.

Nickols GA, Metz MA \& Cline WH Jr 1986 Endotheliumindependent linkage of parathyroid hormone receptors of rat vascular tissue with increased adenosine $3^{\prime}, 5^{\prime}$-monophosphate and relaxation of vascular smooth muscle. Endocrinology 119 349-356.
Nickols GA, Nickols MA \& Helwig JJ 1990 Binding of parathyroid hormone and parathyroid hormone-related protein to vascular smooth muscle of rabbit renal microvessels. Endocrinology 126 721-727.

Pang PK, Tenner TE Jr, Yee JA, Yang M \& Janssen HF 1980a Hypotensive action of parathyroid hormone preparations on rats and dogs. PNAS 77 675-678.

Pang PK, Yang M, Oguro C, Phillips JG \& Yee JA 1980 b Hypotensive actions of parathyroid hormone preparations in vertebrates. General and Comparative Endocrinology 41 135-138.

Pang PK, Harvey S, Fraser R \& Kaneko T 1988 Parathyroid hormone-like immunoreactivity in brains of tetrapod vertebrates. American Journal of Physiology 255 R635-R642.

Philbrick WM, Wysolmerski JJ, Galbraith S, Holt E, Orloff JJ, Yang KH, Vasavada RC, Weir EC, Broadus AE \& Stewart AF 1996 Defining the roles of parathyroid hormone-related protein in normal physiology. Physiological Reviews 76 127-173.

Rian E, Jemtland R, Olstad OK, Endresen MJ, Grasser WA, Thiede MA, Henriksen T, Bucht E \& Gautvik KM 1994 Parathyroid hormone-related protein is produced by cultured endothelial cells: a possible role in angiogenesis. Biochemical and Biophysical Research Communications 198 740-747.

Schluter KD \& Piper HM 1998 Cardiovascular actions of parathyroid hormone and parathyroid hormone-related peptide [see comments]. Cardiovascular Research 37 34-41.

Schulze MR, Mugge A, Harms HM, Cremer J, Frombach R \& Lichtlen PR 1993 Human parathyroid hormone dilates both pig coronary and human inferior epigastric arteries by a cyclic AMPdependent pathway. Artery 20 147-162.

Sham JSK, Chiu KW \& Pang PK 1984 Hypotensive actions of snake parathyroid glands. General and Comparative Endocrinology $\mathbf{5 2}$ 373-377.

Simeoni U, Massfelder T, Saussine C, Judes C, Geisert J \& Helwig JJ 1994 Involvement of nitric oxide in the vasodilatory response to parathyroid hormone-related peptide in the isolated rabbit kidney. Clinical Sciences 86 245-249.

Sutliff RL, Weber CS, Qian J, Miller ML, Clemens TL \& Paul RJ 1999 Vasorelaxant properties of parathyroid hormone-related protein in the mouse: evidence for endothelium involvement independent of nitric oxide formation. Endocrinology 140 2077-2083.

Urena P, Kong XF, Abou-Samra AB, Juppner H, Kronenberg HM, Potts JT Jr \& Segre GV 1993 Parathyroid hormone (PTH)/PTHrelated peptide receptor messenger ribonucleic acids are widely distributed in rat tissues. Endocrinology 133 617-623.

Wang R, Wu LY, Karpinski E \& Pang PK 1991 The effects of parathyroid hormone on L-type voltage-dependent calcium channel currents in vascular smooth muscle cells and ventricular myocytes are mediated by a cyclic AMP dependent mechanism. FEBS Letters $282331-334$

Received 10 November 2000

Accepted 6 April 2001 